\title{
Optimizing the Applications of Criminal Fines Against Electronic Technology Information Crime Based on the Principles of Let Punishment Fit the Crime
}

\author{
Lilyana Tasya Kurniawan ${ }^{1,2}$, Ade Adhari ${ }^{2 *}$
}

\author{
${ }^{1}$ Faculty of Law, Universitas Tarumanagara, Jakarta, Indonesia \\ ${ }^{2}$ Lecturer of Criminal Law, Faculty of Law, Universitas Tarumanagara, Jakarta, Indonesia \\ Jl. Letjen. S. Parman No. 1 West Jakarta 11440, Indonesia \\ Corresponding author,Email: adea@fh.untar.ac.id
}

\begin{abstract}
Currently technological developments have led to an increase in criminal acts in the field of the technology electronic information. One of them are a criminal act committed by person who manipulating data as if the transaction was authentic and has actually happened. The actor invites several other people to make fictitious transactions of buying and selling vouchers using fictitious accounts and fictitious addresses. The perpetrators used the address of a relative or a people who they known without the owner knowing it was being used for fictitious transactions, losses of up to billions of rupiah to the Tokopedia company. In the court decision of Malang city court, the perpetrator is only given imprisonment and light fines. It isn't comparable to the deeds and what is written in the laws of the technology electronic information the question arises how the application of criminal penalties that can be applied optimally and whether the criminal sanctions given are based on justice. The research of method is normative legal research and uses a statutory approach and a case approach, the research of data obtained through literature study. The conclusions results show that the use of fines in overcoming crimes in the information technology sector is not optimal. Giving punishment proportionally between action and punishment, it provides justice and provides learning for the perpetrators of other criminal acts. This study is to provide education to the public and particular to judges because they are wiser in making decisions against perpetrators of the technology electronic information.
\end{abstract}

Keywords: Technology electronic information, crime, electronic information crime, punishment, imprisonment sanctions, criminal penalties

\section{INTRODUCTION}

The level of criminal offenses for the technology electronic information increases over time and is influenced by technological developments. During January 2020 to December 2020 there were 2.259 criminal cases reports in the electronic information crime sector in Indonesia based on official information from the Cyber Patrol website. [1]

The types of criminal acts committed by the perpetrators are regulated in articles 27 to 35 of Law of the Republic of Indonesia Number 11 of 2008 concerning amendments to Law of the Republic of Indonesia Number 19 of 2016 concerning Electronic Information. After observing the types of criminal acts, there was one criminal cases in the electronic information crime field that was committed by a person named Sihabudin who manipulated the data as if it were authentic.

The mode of this case is the main perpetrator inviting several other people to conduct fictitious transactions. The main actor has succeeded in getting three other people to conduct fictitious transactions. The fictitious transaction was carried out by buying and selling vouchers shopping through the online shopping Tokopedia using by thousands of fake accounts and fictitious addresses. Did not only using personal residential addresses.

The three perpetrators have also used the residential address of another person without they knowing of the owner of the address to become the target of the fictitious transaction. The actors benefit from the cashback provided by Tokopedia as a way for companies to carry out company promotions. For this action, Tokopedia suffered a loss of Rp1.705.355.696.00 (one billion seven hundred five million three hundred fifty-five thousand six hundred and ninety-six rupiah). For the actions of the perpetrators, the Malang District Court Judge sentenced him to imprisonment of 4 (four) years and 6 (six) months and a fine of Rp10.000.000.00 (ten million rupiah). Meanwhile, the application of the electronic information crime law, namely imprisonment sanctions that are given for a 
maximum of 12 (twelve) years and fine sanctions given with a maximum fine of Rp12.000.000.000.00 (twelve billion rupiah).

The verdict that has been decided by the judge has not reflected the optimal implementation of the criminal sanction based on the principle of let punishment fit the crime. There is a considerable difference between what has been decided by the judge and what has been regulated in the statutory regulations. Based on the above case, the provision of a large enough fine in accordance with statutory regulations is deemed appropriate with the actions committed by the perpetrator. Imposing fines can be used as a legal consequence as a result of the perpetrator's actions. If the small criminal sanction is too small, there will be no balance between the act and the imposition of criminal sanctions received by the perpetrator.

The provision of large fines is in accordance with the concept of punishment from Cesare Beccaria in his book entitled De Elitti e Delle Pene or On Crimes and Punishments, namely let punishment fit the crime. [2] With the provision of a large enough nominal fine, it will give a strong warning and will be more effective in suppressing the perpetrator of a criminal act. Beccaria argues that ideally a punishment for a crime committed by the perpetrator should be calculated based on his actions let the punishment fit the crime. [3] Based on Beccaria's opinion, the application of fines should be used as an alternative to imposing criminal sanctions. Based on these reasons the title of this research was appointed, "Optimizing the Applications of Criminal Fines Against Electronic Technology Information Crime Based on the Principles of Let Punishment Fit The Crime".

\subsection{Related Work}

This paper presents several criminal law related to Electronic Information Technology criminal cases which are appointed into several categories.

\subsubsection{The criminal justice system}

Definition of the criminal justice system according to Mardjono Reksodiputro is a system in society that has a function to deal with crime problems. The meaning of dealing with it has the meaning as a way of controlling crime so that it remains within the limits of tolerance. [4] Based on the opinion of experts in the criminal justice system, 3 (three) important components are needed to help the performance of the criminal justice run smoothly. This component starts from the law enforcement process through the police agency. Then it is further processed in court through judges, prosecutors and advocates as a consequence and how the perpetrator must be responsible for the criminal act his violated. The last component is the correctional institution through correctional officers and assistance agency officers. The last stage is the way of coaching so that the perpetrators of criminal acts receive learning and character improvement so that there is a deterrent effect and pressure the perpetrators of criminal acts not to commit the crime again. Cavadino and James Digna have an opinion regarding the criminal justice system, the criminal system is a process or stage of crime.

\subsubsection{Criminal law policy}

Definition of criminal law policy can be understood in several words from foreign languages. policy comes from the Dutch language, namely "politiek". Criminal law policy can also be regarded as criminal law politics. Criminal law politics also has several terms using foreign languages, namely "penal policy", "criminal law policy" or "strafrechts politiek" [6].

According to Hamdan, criminal policy is a rational attempt by civil society to deal with crime / crime problems. These efforts include activities starting from the formation of policies or laws and regulations, the performance of law enforcement agencies, courts and officials for the execution of the punishment. A Mulder argues that the existing criminal system in society has a criminal law system consisting of criminal law regulations and sanctions. A criminal law procedure and an implementation mechanism of the criminal law itself. Efforts and policies to make an ideal statutory regulation in essence cannot be separated from the goal of overcoming crime. [7] Criminal law enforcement policies. criminal law enforcement policy is a sequence/process of several policy stages.

The first stage is the formulation policy or the legislative policy stage. The formulation stage is law enforcement in abstracto by the legislative body through the legislature. The second stage is the application policy or the judicial policy stage. The application stage is a process or sequence carried out by law enforcement officials starting from the police agency to the court institution. The third stage is the policy execution stage or the executive or administrative policy stage. The administrative stage is the stage of implementing criminal law in a real way by enforcement officers criminal [8].

\subsubsection{Conditions for criminalization}

The perpetrator of a criminal act can be deemed to have committed a criminal act, if his actions or actions have been proven to be criminal acts in accordance with statutory regulations that have been made by the legislative body. Conditions are given if the person has committed a criminal act and how the perpetrator is responsible for the wrong he has committed. According to Van Hamel, a criminal act is an act that is committed either intentionally or unintentionally by the perpetrator of a criminal act by holding his accountable for a crime committed in accordance with what has been violated in the law.

In the normative aspect of a criminal act, it means that a criminal act is a prohibition on the act to be committed. The prohibition is related to the nature of indecency in his actions. From the functional aspect, criminal acts have the 
function of giving warnings to the public about acts that are prohibited and punishable in accordance with existing regulations. Philosophically, criminal acts represent the public interest of society and create order in society [9].

The second condition is the accountability of the criminal offender. If a person has been proven to have committed a criminal act, the perpetrator must be held for criminal liability. The thing that is the basis of criminal Liability is error. The definition of criminal error in the broadest sense is liability in criminal law. The definition of error in the narrow sense of error can be in the form of intention (opzet) or negligence (culpa) [10].

Mistakes always have to do with the person who commits a crime. For these mistakes, the mistakes have two important things, namely those that can be reproached for actions and those that should be avoided for actions against the law. Error has 3 elements that underlie the error. The first element of error is one's ability to take responsibility. The second element is the relationship between the perpetrator and his actions in the form of deliberate dolus and negligence or culpa which is a form of error. The last element is that there is no excuse that can erase mistakes or excuses for forgiveness [11].

\subsubsection{Criminal}

After understanding the terms of punishment, the definition of modern punishment according to Wesley Cragg, there are 4 components related to punishment. The first component of the first component of punishment is an important event and the perpetrators of criminal acts who have committed criminal acts in civil society cannot avoid the punishment process. [12] The second component of conviction is a series of criminal justice systems that are always evolving and there are types of crimes that cannot be separated from the types and characteristics of the crimes committed by the perpetrator.

The third component of mandatory enforcement underwent highly visible changes based on the implementation in Western Europe North America. The fourth component of the number of sentences used must provide efforts for the execution of the crime to be in accordance with the punishment itself. The division of criminal sanctions consists of two categories, namely principal and additional crimes.

The main criminal sanctions are capital punishment, imprisonment, fines and imprisonment. Furthermore, the forms of additional criminal sanctions are revocation of certain rights, confiscation of certain items and announcement of a judge's decision. The purpose of punishment is a means of community protection, rehabilitation, resocialization, fulfillment of traditional law views, as well as psychological aspects to eliminate guilt for the perpetrator. [13] Criminal law. After seeing the purpose of punishment, there are several theories of punishment. Criminal theory is divided into three kinds of theories which include absolute theory or retaliation theory, relative theory or objective theory and combined theory.

\subsubsection{The theory of let punishment fit the crime}

Cesare Beccaria is a philosopher from Italy who became a pioneer in reforming the theory of punishment by giving a new term, namely let the punishment fit the crime. Beccaria wrote an opinion and criticism of punishment in his era which was deemed incompatible with the conditions of society in of that era. The book he wrote entitled Dei delitti e delle pene. In his book Beccaria states his opinion on the principles of punishment according to Beccaria, namely: [14]

Prioritizing the goal of preventing crime (preventive) rather than punishing crime (punitive); Measuring the level of crime committed by the perpetrator of a criminal act based on the level of public loss; Making the function of punishment as an instrument social; Making the punishment effective with special provisions, such as light, direct, consistent, prompt, proportional, certain, appropriate, and non-discriminatory criminal sanctions and criminal acts obtained by the perpetrator of a criminal act must be balanced and proportional to the crime and the penalty for imposing a fine should be adjusted using the appropriate scale of action and scale of punishment.

Starting from the most severe to the lightest if there is an appropriate and universal scale of crime and punishment, it must have an estimate and a global measure of the gradation of tyranny and freedom. Yes, it shows that there is agreement with Beccaria's theory. Let punishment fit the theory has a center for the imposition of punishment based on the type that the perpetrator of the crime has committed to be balanced with the imposition of sanctions to be received. Imposing a crime that is too cruel like the death penalty will not fully guarantee the elimination of the same crime so that it does not happen again [15].

\subsection{Our Contribution}

This paper presents the formulation of a problem regarding how to implement criminal sanctions against criminal acts of electronic technology information based on the principle of let punishment fit the crime. Does the application of criminal sanctions to criminal acts of electronic transaction information in the decision reflect justice. This paper also has the aim of analyzing the laws and regulations applicable in Indonesia. The use of this research is to broaden the knowledge of law, especially criminal law. This research has practical uses for judges. Judges can see this research as a reference for the application of the principle of let punishment fit the crime in the imposition of crimes in general and fines in particular whether or not they should have been running.

\subsection{The Paper Structure}

Structure of this paper consists of 3 parts. The first part contains an introduction. The second part contains a discussion and the third part is the conclusions and suggestions that can be given to this research. The type of 
research used in this research is normative or doctrinal legal research. The research specification that will be used in this research is prescriptive research. The type of data and data collection in this research is qualitative data and literature study data collection. The research approach used is the statute approach and the case approach. The data analysis technique is deductive reasoning by paying attention to the major premises and minor premises in this study.

\section{BACKGROUND}

\subsection{Of the Criminal Justice System}

Electronic technology information crimes that are rife in Indonesia, especially in Indonesia, must be resolved immediately. Settlement of criminal acts can be resolved through punishment. Perpetrators can be penalized if they have been proven to have committed violations stated in the laws and regulations for their mistakes by being responsible for the crime through the criminal justice system.

The criminal justice system according to black laws is a system used to tackle criminal acts through a process that starts from the initial arrest to the trial process and prisons to foster criminal offenders so that they do not commit the same crime again [16].

\subsection{Crime}

The definition of a criminal act is an act which is prohibited by law and punishable by the perpetrators who have violated it. With this criminal act, the perpetrator of the crime can be held accountable. Types of criminal acts in the field of electronic information technology include: Creating and distributing electronic content or documents that have elements of actions that violate decency; Having created and disseminated content or electronic documents that have elements of an act that violates gambling; Create and disseminate defamatory content or electronic documents;

Creating and distributing electronic content or documents that have elements of the threat, whether done individually or in groups; Create and disseminate fake news content that causes consumer losses in electronic transactions; Creating and distributing electronic content or documents that have elements to create hatred for individuals with the theme of ethnicity, intergroup, race and religion; Create and disseminate content or electronic documents that have elements of threatening violence or scare that are intended for personal use; Trying to access a computer using an electronic system in various ways in order to get certain information; trying to access computers and electronic documents in various ways that violate, break through, bypass, or break into security systems; Attempting to manipulate data on the creation, alteration, removal, destruction of electronic documents with the aim that the electronic document or data is considered as if the data is authentic and actually occurs; give a lawsuit against certain parties who sued him electronically using information technology and causing losses.

\subsection{Criminal Responsibility}

According to Samson, responsibility is a person's mental psychic state so that the application from a public and personal point of view is deemed appropriate. The thing that becomes the foundation of criminal responsibility is the psychological state (mental condition) which is interrelated between the conditions of the surrounding environment and the actions he has committed [17].

Responsibility functionally is accountability that is centered on legal obligations so that the perpetrators of the crime carry out and comply with the legal norms applicable in society. As a result of not fulfilling legal obligations, there is a legal basis for a criminal imposition. Meanwhile, philosophical accountability is a norm aimed at judges in order to decide and determine the existing circumstances as the basis for the conviction of the perpetrator of the crime.

\subsection{Types of Electronic Information Criminal Sanctions}

In statutory regulations, criminal offenders will be given criminal sanctions based on article 45 to article 51 of Law number 11 of 2008 on amendments to law number 19 of 2018 concerning electronic technology information are imprisonment and fines. PAF Lamintang explained that imprisonment is a crime that limits the freedom of movement of a convicted person, which is carried out by closing the person in a correctional facility. Obliging the person to obey all rules and regulations that apply in the correctional facility associated with a criminal act that they have violated. [18] While a fine is a criminal sanction given which has the aim of paying a nominal amount of money as stipulated in the law to the perpetrator who has violated a criminal act.

The imposition of a criminal penalty is a consequence of the loss caused by the actions of the perpetrator and restoring the function of legal rules that have been violated the criminal regulation of fines as stipulated in article 45 , article $45 \mathrm{~A}$, article $45 \mathrm{~B}$, article 46, article 47, article 48, article 49, article 50 and article 5 law Number 11 Year 2008 regarding amendments to law number 19 of 2018 concerning electronic technology information.

\subsection{Let Punishment Fit the Crime}

This theory is an opinion expressed by Cesare Beccaria because according to him there were arbitrary actions taken by law enforcers to civil society and there was no equality between groups in society who committed a mistake, according to Beccaria's theory of punishment in principle, it has similarities and is in line with general principles that are considered fair in the paradigm of utilitarian punishment. 
According to Cessare Beccaria, main reforms during the era include: [19]

2.5.1 The quality of the community must be formed based on the principle of a social contract.

2.5.2. The thing that must be used as a source of law is the law and not based on the judge.

2.5.3 The duty of a judge is limited to determining the guilt of a criminal offender.

2.5.4 Punishing someone who has committed a criminal act is a right for the state, and this right is necessary to protect society from individual greed.

2.5.5 There shall be a scale of comparison between the crime and the punishment that is balanced with the crime and the consequences of the losses incurred by the perpetrator of the criminal act.

2.5.6 Human motives are basically based solely on the advantages and disadvantages, considering the pleasure and misery that the criminal offender receives.

2.5.7. The basis for determining the punishment is the act and not based on the intention of the perpetrator of the crime (let punishment fit the crime).

Beccaria sees directly and in accordance with the fact that Beccaria feels disappointed with the government in power at a certain time and is highly critical of disproportionate penalties. Beccaria advises that the government does not need to punish individuals excessively like the death penalty. Beccaria is of the view that even death penalty will not guarantee one hundred percent to suppress or eliminate the crime so that it will not happen again. The perpetrators of criminal acts will start thinking about avoiding the first sentence because there is a death penalty. They will still choose to commit other crimes to avoid the death penalty. Therefore, Beccaria emphasizes on his theory to regulate so that there is a balance and proportionality between the crime committed and the punishment that the criminal offender will receive as a consequence of the crime he has committed [20].

Relationship between the above criminal theories and fictitious transaction criminal cases that occur in online shopping media Tokopedia focuses on imprisonment and fines that do not reflect the optimization of criminal sanctions.

This is evident in article 35 paragraph of law number 11 of 2008 regarding the amendment of law number 19 of 2018 concerning electronic technology information, namely: "Everyone deliberately and without rights or against the law manipulates, creates, changes, removes, damages. Electronic Information and/or electronic documents with the aim that electronic information and/or Electronic Documents are considered as authentic data".

Article 51 paragraph 1 of Law number 11 of 2008 regarding the amendment of law number 19 of 2018 concerning electronic technology information reads, namely:

"Every person who meets the elements as referred to in Article 35 shall be sentenced to imprisonment of up to 12 (twelve) years and/or a maximum fine of Rp12.000.000.000.00 (twelve billion rupiah)".

Objective elements:

Actions: manipulation, creation, alteration, removal or destruction is done on purpose.

The object: electronic information and/or electronic documents with the aim that the electronic information and/or electronic documents are considered as authentic data.

Subjective element: everyone. In this subjective element, there are 5 (five) criminal acts regulated in article 35 of the electronic information crime law, namely manipulation, creation, alteration, disappearance or destruction. The object of crime which is also the second object of the act is electronic and/or electronic information. The crime is committed on purpose. The meaning of an act that is done deliberately is the perpetrator of a criminal offense for his action because of an intention. Sihabudin's understanding of an intention was to manipulate data by creating thousands of fake accounts for personal gain.

Punishable by imprisonment, namely 4 (four) years and 6 (six) months and a fine of Rp10.000.000.00 (ten million rupiah) for having committed an illegal act, namely the manipulation of electronic information and/or electronic documents that appear authentic. against the buying and selling of vouchers Indomaret conducted by Sihabudin. The criminal act was guilty because the crime was committed consciously by inviting the cooperation of three other perpetrators which resulted in billions of rupiah in losses. Sihabudin is a perpetrator who is 24 years old and is legally valid and can be accountable for his conscious actions.

Imposing criminal sanctions for criminal acts committed against the Tokopedia company has not been able to reflect the optimal application of criminal sanctions. For the actions committed by Tokopedia actors, they suffered material losses of up to 1 billion more and immaterial losses, namely a decrease in the public's sense of trust to shop online. Imprisonment is only 4 (four) years and 6 (six) months and a fine of Rp10.000.000.00 (ten million rupiah).

\subsection{Application of Criminal Sanctions Based on the Principle of Let Punishment Fit the Crime}

The application of criminal sanctions is not optimal because there is a very large gap between what is regulated in the law with this criminal act. With this, it is also not in line with the thoughts and theories put forward by Beccaria, namely regarding let punishment fit the crime. The judge should have been able to give criminal sanctions in accordance with the actions of the perpetrator. Judges as the state's authoritarian institution which are at the forefront of punishment should be wiser in making decisions. The judge should be able to give a fine and imprisonment that is close to what is stipulated in the statutory regulations and is in accordance with the criminal act of the loss suffered by the victim. With the stipulation 
of a large enough fine, it will have an effect on society not to commit the same crime. If it is related to money, the public will think again about committing a criminal act. People tend to avoid criminal acts related to criminal sanctions with large nominal fines. People in the current era tend to have prison rather than having to lose a lot of money from their hard work for their criminal acts. With this viewpoint, criminal sanctions can be considered very effective in suppressing criminal acts in the field of electronic information technology.

\section{CONCLUSION}

The crime rate of information electronic technology crime is increasing over time and is influenced by technological developments. During January 2020 to December 2020 there were 2,259 criminal case reports in the eletronic information crime sector in Indonesia based on official information from the Cyber Patrol website. The types of criminal acts committed by the perpetrators are regulated in articles 27 to 35 of Law of the Republic of Indonesia Number 11 of 2008 concerning amendments to Law of the Republic of Indonesia Number 19 of 2016 concerning Electronic Information. After observing the types of criminal acts, there is a criminal case in the eletronic information field committed by a consumer who manipulates data as if it were authentic.

For the actions of the perpetrators, the Malang District Court judge sentenced him to imprisonment of 4 (four) years 6 (six) months and a fine of Rp10.000.000.00 (ten million rupiah). Meanwhile, the application of criminal sanctions in Article 35 of the electronic information crime law are imprisonment penalties for a maximum of 12 (twelve) years and a maximum fine of Rp12.000.000.000.00 (twelve million rupiah). The verdict that has been decided by the judge has not reflected the optimal implementation of the criminal sanction based on the principle of let punishment fit the crime. Based on the above case, the provision of a large enough fine in accordance with statutory regulations is deemed appropriate with the actions committed by the perpetrator. If the small criminal sanction is too small, there will be no balance between the act and the imposition of criminal sanctions received by the perpetrator. The provision of large fines is in accordance with the concept of punishment from Cesare Beccaria in his book entitled De Elitti e Delle Pene or On Crimes and Punishments, namely let punishment fit the crime. With the provision of a large enough nominal fine, it will give a stern warning and will be more effective in pressuring other criminal offenders did not to do the same thing. If it is related to money, the public will think again about committing a criminal act. People tend to avoid criminal acts related to criminal sanctions with large nominal fines. People in the current era tend to have prison rather than having to lose a lot of money from their hard work for their criminal acts. With this point, criminal sanctions can be considered very effective in suppressing criminal acts in the field of electronic information technology.

\section{ACKNOWLEDGMENT}

This work is supported by the International Conference on Economics, Business, Social, and Humanities (ICEBSH), Faculty of Law, Tarumanagara University, Jakarta, Indonesia

\section{REFERENCES}

[1] Patroli Siber. "Statistik Jumlah Laporan Polisi yang dibuat Masyarakat". https://www.patrolisiber.id/statistic

[2] M. Nur Prabowo. S.C Beccaria \& Voltaire, Tentang Kejahatan dan Hukuman. 2017 (Yogyakarta: Lintas Nalar). Page. 13.

[3] E. Harcour, Beccaria's On Crimes and Punishments: A Mirror on the History of the Foundations of Modern Criminal Law. 2013. (Public Law and Legal Theory Working: Paper NO. 433). Page 13.

[4] E. Setiadi dan Kristiani. Sistem Peradilan Pidana Terpadu dan Sistem Penegakan Hukum Di Indonesia. 2017. (Jakarta: Kencana). Page. 18

[5] T. Effendi. Sistem Peradilan Pidana: Perbandingan Komponen dan Proses Sistem Peradilan Pidana di Beberapa Negara. 2013. (Yogyakarta: Medpress Digital). Page. 10

[6] B.N. Arief. Bunga Rampai Kebijakan Hukum Pidana (Perkembangan Penyusunan Konsep KUHP Baru), 2010, (Jakarta: Kencana Prenada Media Group). Page. 26.

[7] T. Asmarawati. Pidana dan Pemidanaan dalam Sistem Hukum Indonesia. (Hukum Penitensier), 2015, (Yogyakarta: Dee Publish). Page 39

[8] B.N. Arief, Bunga Rampai Kebijakan Hukum Pidana (Perkembangan Penyusunan Konsep KUHP Baru). 2010. (Jakarta: Kencana Prenada Media Group). Page. 119.

[9] I. Gunadi. Cepat dan Mudah memahami Hukum Pidana.2014. (Jakarta: Kencana). Page 13.

[10] R. Ariman dan F. Raghib. Hukum Pidana, 2016. Malang: Setara Press. Page. 25.

[11] Sudarto. Hukum Pidana 1. 2018. (Semarang: Yayasan Sudarto). Page 115.

[12] Eddy O. S. Hiariej. Pustaka Prinsip-Prinsip Hukum Pidana. 2015 (Yogyakarta: Cahaya Atma Pustaka). Page. 451. 
[13] Article 10 of the Criminal Code.

[14] Ibid, M. Nur Prabowo. S, Op. Cit. Page. 391.

[15] Bernard. E. Harcourt Op. Cit. Page 9.

[16] Eddy. O. S, Op. Cit. Page. 251.

[17] Muhammad Ainul Syamsu. Penjatuhan Pidana \& Dua Prinsip Dasar Hukum Pidana.2016 (Jakarta: Prenadamedia). Page. 16.

[18] C. Djisman Samosir. Sekelumit Tentang Penologi \& Pemasyarakatan. 2015 (Bandung: Nuansa Aulia). Page. 53.

[19] M. Nur Prabowo. S, Op. Cit. Page. 391.

[20] Law teacher. Let the Punishment Fit Crime. https://www.lawteacher.net/free-law-essays/ criminology/let-the-punishment-fit-the-crime 